Abstracta Iranica

Revue bibliographique pour le domaine irano-aryen

Volume 37-38-39 | 2018

Comptes rendus des publications de 2014-2016

\title{
James Howard-Johnston. «The Grand Strategy of the Sasanian Empire »
}

\section{Rika Gyselen}

\section{(2) OpenEdition \\ 12 Journals}

\section{Édition électronique}

URL : http://journals.openedition.org/abstractairanica/42645

DOI : 10.4000/abstractairanica.42645

ISBN : 1961-960X

ISSN : 1961-960X

Éditeur :

CNRS (UMR 7528 Mondes iraniens et indiens), Éditions de l'IFRI

Référence électronique

Rika Gyselen, « James Howard-Johnston. «The Grand Strategy of the Sasanian Empire » », Abstracta Iranica [En ligne], Volume 37-38-39 | 2018, document 17, mis en ligne le 10 mars 2018, consulté le 28 septembre 2020. URL : http://journals.openedition.org/abstractairanica/42645 ; DOI : https://doi.org/ 10.4000/abstractairanica. 42645

Ce document a été généré automatiquement le 28 septembre 2020.

Tous droits réservés 


\title{
James Howard-Johnston. « The Grand Strategy of the Sasanian Empire »
}

\author{
Rika Gyselen
}

\section{RÉFÉRENCE}

James Howard-Johnston. «The Grand Strategy of the Sasanian Empire », in C. Binder, H. Börm, A. Luther (ed.), Diwan. Untersuchungen zu Geschichte und Kultur des Nahen Ostens und des östlichen Mittelmeerraumes im Altertum. Festschrift für Josef Wiesehöfer zum 65. Geburtstag, Duisburg, Wellem Verlag, 2016, p. 591-613.

1 L'auteur considère que "la grande stratégie de l'empire sassanide » est liée à trois attitudes distinctes. La première démarche est appelée "impérialisme passif ou inerte ", c'est-à-dire l'absence de la part des Sassanides d'affirmer leur prétention de vouloir élargir leur territoire (vers l'ouest). Le deuxième aspect se concrétise par « une orientation géopolitique vers l'est de l'empire » qui est lié à un changement au $\mathrm{V}^{\mathrm{e}}$ siècle de l'idéologie dynastique qui renoue avec son passé légendaire kayanide dans lequel il fallait tenir le Turān à distance. Le troisième élément s'inscrit dans la poursuite des intérêts commerciaux. 


\section{AUTEURS}

\section{RIKA GYSELEN}

CNRS, Mondes iranien et indien 